\title{
Amalan Standard Halal Di Negara-Negara Asia Tenggara
}

\author{
Mohd Al'Ikhsan Ghazali ${ }^{a}$, Siti Salwa Md. Sawari ${ }^{\mathrm{a}}$ \\ ${ }^{a}$ Fakulti Tamadun Islam, Unversiti Teknologi Malaysia \\ *Corresponding author: salwa.sawari@gmail.com
}

Article history
Received: $2014-08-26 \quad$ Received in revised form: 2014-09-19 Accepted: 2014-11-04

\begin{abstract}
Halal global market shows a significant growth in line with the increasing numbers of world Muslims population. The increasing demand of halal products market is expected to continue to rise in the future. It is therefore, a need to have a standard implementation for halal product all over the world in order to assure the uniformity of halal certification accreditation. By such, this study is to investigate halal standards, and its implementations in Asian countries. In conducting this study, a qualitative approach was applied by utilising library research in collecting the related data. Result of this study indicates that halal standards in Malaysia and other South East Asian countries (Indonesia, Thailand, Brunei and Singapore) are regulated and governed by their own responsible party. Referring to the implementation halal standard, each country has its own characteristics of halal assurance system.
\end{abstract}

Keywords: South East Asian Countries, Standard Halal, Assurance system.

\begin{abstract}
Abstrak
Pasaran produk halal di peringkat global menunjukkan peningkatan yang memberangsangkan selari dengan meningkatnya jumlah umat Islam di dunia. Peningkatan pasaran produk halal ini berlaku secara berterusan tanpa menunjukkan sebarang penurunan. Sejajar dengan peningkatan permintaan makanan halal, standard halal perlu dilaksanakan bagi memastikan keseragaman berlaku. Oleh yang demikian, Kajian ini di jalankan bagi melihat standard halal, penguatkuasaan dan perlaksanaan yang dilaksanakan oleh Negara-negara di Asia? Kajian ini berbentuk kualitatif. Oleh yang demikian, pengkaji telah memilih untuk menggunakan metode kajian perpustakaan bagi mendapat data kajian. Hasil kajian ini telah membuktikan bahawa standard halal yang digunakan di Malaysia dan Negara di Asia (Indonesia, Thailand, Brunei dan Singapura) adalah diselia oleh pihak bertanggungjawab. Merujuk kepada standard halal yang digunakan, setiap negara mempunyai ciri-ciri jaminan yang tersendiri.
\end{abstract}

Kata kunci: Negara-Negara Asia Tenggara, Standard Halal, Jaminan. 


\subsection{PENDAHULUAN}

Pasaran produk halal di peringkat global semakin menunjukkan peningkatan yang memberangsangkan selari dengan meningkatnya populasi umat Islam dunia (Kementerian Perdagangan Indonesia, 2012). Menurut editor Warta Eksport (2013) peningkatan pasaran produk halal ini berlaku secara berterusan tanpa menunjukkan sebarang penurunan. Tambahan pula kesedaran di kalangan masyarakat dunia telah meningkat apabila mereka mula memahami bahawa konsep halal yang di bawa oleh Islam adalah bersifat universal, komprehensif dan bukan bersifat keagamaan semata-mata. Tanda aras keselamatan dan kebersihan yang menjadi fokus utama dalam konsep halal telah menyebabkan permintaan yang tinggi dari kalangan umat Islam dan bukan Islam tanpa mengira bangsa atau keturunan (Norakilah Omar, 2007). Permintaan terhadap produk halal ini bukan sahaja meliputi produk makanan semata, bahkan ia merangkumi peningkatan permintaan terhadap produk seperti kosmetik, perubatan dan bahan gunaan (Zawanah Muhammad, et al. 2008). Maka dengan permintaan makanan halal yang semakin meningkat ini, standard halal perlu dilaksanakan bagi memastikan keseragaman berlaku. Oleh yang demikian, Kajian ini di jalankan bagi melihat standard halal, penguatkuasaan dan perlaksanaan yang dilaksanakan oleh negaranegara di Asia.

\subsection{HALAL}

Perkataan halal berasal daripada perkataan Arab yang termaktub dalam al-Quran iaitu halla, yahillu, hillan, wahalalan yang membawa maksud dibenarkan atau dibolehkan (Zawabah, Munir \& Abdul Muhaimin, 2011). Konsep halal dalam Islam tidak hanya berkisar kepada persoalan keharusan sesuatu makanan atau produk itu boleh dimakan dan digunakan atau tidak. Ia bermaksud sesuatu yang dibolehkan oleh undang-undang Islam (syarak), diizinkan, dibenarkan melalui cara yang sah. Penjelasan tentang perintah mencari makanan yang halal telah jelas diterangkan di dalam surah al -Baqarah:168

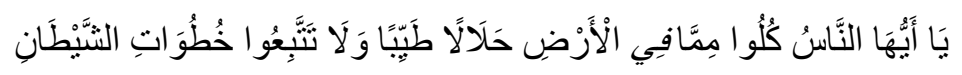

Ertinya: Wahai manusia, makanlah dari apa yang ada di bumi Allah ini, yang halal dan baik-baik. Janganlah kamu mengikut jejak langkah syaitan kerana sesungguhnya syaitan itu adalah musuh kamu yang paling nyata.

Ini diperkuatkan lagi dengan penjelasan dari Hadis Nabi,

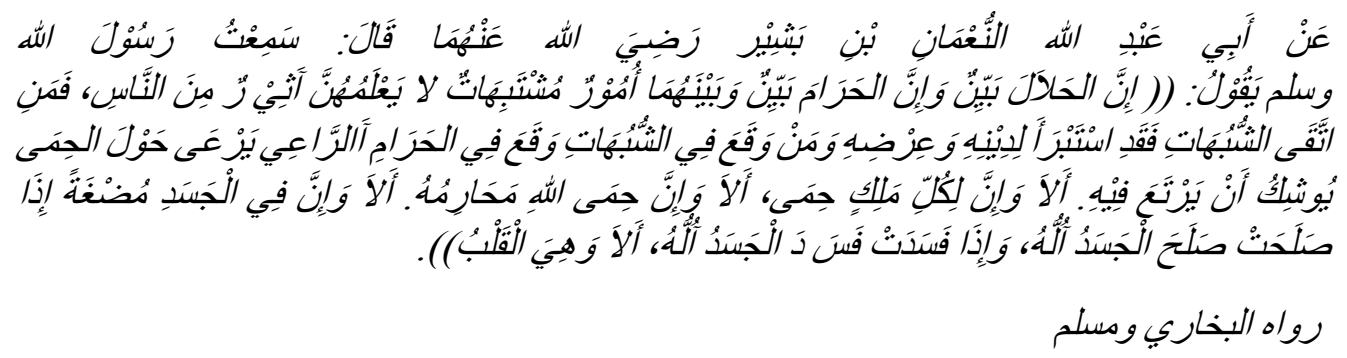

maksudnya: Daripada Abu Abdullah al-Nu'man ibn Basyer r.a. beliau berkata: Aku telah mendengar Rasulullah SAW bersabda: Sesungguhnya perkara yang halal itu terang jelas, dan sesungguhnya perkara yang haram itu terang jelas, dan di antara kedua perkara tersebut ada perkara-perkara syubhat yang kesamaran yang kebanyakan orang tidak mengetahuinya. Barang siapa yang menjaga perkara syubhat maka sesungguhnya dia telah membersihkan agamanya dan maruah dirinya. Dan barang siapa yang terjatuh dalam perkara syubhat, maka dia telah jatuh dalam perkara haram, umpama seorang penggembala yang menggembala di sekeliling kawasan larangan, dibimbangkan dia akan 
menceroboh masuk ke dalamnya. Ketahuilah bahawa setiap raja ada sempadan dan sesungguhnya sempadan Allah itu ialah perkara-perkara yang diharamkanNya. Ketahuilah bahawa dalam setiap jasad itu ada seketul daging yang apabila ia baik maka baiklah seluruh jasad dan apabila ia rosak, maka rosaklah seluruh jasad. Ketahuilah ia adalah hati.

\section{HR al-Bukhari dan Muslim}

Portal Rasmi Halal Malaysia (2011) menyatakan bahawa konsep halal merujuk kepada setiap benda yang terhindar dari segala najis, dan mana-mana bahagian binatang yang haram di makan sama ada disebabkan zat aslinya atau proses penyediaan yang tidak menepati syarak. Proses penyediaan yang tidak menepati syarak ini merangkumi juga kepada cara penyediaan dan peralatan yang digunakan dalam masa proses tersebut. Maka hendaklah dipastikan bahawa semasa memproses atau menyimpan bahan itu, ia tidak bersentuhan atau diletak berhampiran dengan benda-benda yang di haramkan oleh syarak.

Sementara itu, konsep halal yang diterangkan oleh Yusuf Al-Qardhawi (2013) sebagai sesuatu yang diharuskan, yang terungkai padanya ikatan larangan, dan diizinkan oleh syarak untuk melakukannya. Menurut Yusuf Al Qardawi lagi, halal ini menjadi keindahan Islam apabila ia menghalalkan benda yang perlu untuk hidup dan melarang benda yang tidak bermanfaat sambil memberi alternatif atau pilihan lain kepada umat manusia. Sebagai contohnya Islam telah mengharamkan memakan bangkai namun menyediakan banyak daging segar yang boleh di makan. Islam telah mengharamkan arak tetapi banyak lagi jus buah-buahan yang boleh diminum. Berdasarkan definisi ini, halal dapat dirumuskan kepada sesuatu yang diharuskan Allah SWT kepada manusia untuk memakan, mengguna, dan bermuamalah dengannya. Perkara ini meliputi benda-benda yang terhindar dan suci daripada segala perkara-perkara haram.

Burhan (2000) pula menyatakan konsep halal menjadi satu garis panduan bagi umat Islam dalam semua aspek kepenggunaan (consumerism) dan penggunaan (utilisation) produk dan perkhidmatan makanan halal. Kefahaman konsep halal ini menjurus kepada penggunaan logo dan sijil halal berdasarkan piawaian yang dibina dalam pengurusan kualiti makanan dan produk gunaan yang halal. Nor Aini Haji Idris dan Mohd Ali Mohd Noor (2013) menegaskan bahawa konsep halal adalah satu garis panduan kepada para pengguna bagi mengenal pasti kualiti halal dan kesucian sesuatu produk. Konsep halal yang diperjelaskan dalam Islam telah menjadi satu garis panduan yang komprehensif dan menyeluruh dalam memberi informasi yang tepat kepada para pengguna. Maka dengan itu Jabatan Agama Kemajuan Islam Malaysia (JAKIM) dan Jabatan Agama Islam Negeri (JAIN) di Malaysia telah memainkan peranan mereka dengan memastikan bahawa ketulenan informasi halal yang sampai kepada pengguna adalah benar.

Tambahan pula, isu halal ini bukanlah menjadi hak milik umat Islam sahaja, bahkan ia memberi kepentingan yang amat banyak kepada umat manusia sejagat. Perkara ini diterangkan di dalam tulisan Hayati@Habibah \& Khairul Anuar (2008) yang menyatakan bahawa halal bukan sahaja merupakan satu konsep yang menitikberatkan kepada asas kehendak agama Islam, iaitu kesucian, tetapi turut mengandungi aspek yang luas dari segi rohani dan jasmani sama ada pada produk yang dihasilkan dan pengusaha produk itu sendiri. Jika dirangkumi keseluruhan aspek tersebut, pengaplikasian halal boleh diungkapkan sebagai satu satu konsep yang menjurus kepada pendekatan yang berkonsepkan kualiti, iaitu sesuatu jaminan kualiti khususnya yang melibatkan pemprosesan, pengambilan dan penggunaan sesuatu produk atau perkhidmatan oleh seseorang Muslim. Konsep ini dilihat mematuhi konsep (halalan toyyiban) iaitu bermaksud halal serta baik. Maksud baik di sini bukan hanya terletak kepada kandungan produk tetapi juga meliputi aspek kebersihan dan kesucian sesuatu produk yang dikeluarkan. Maka dengan itu faedah dan manfaat daripada penjenamaan halal ini akan memberi faedah kepada semua manusia.

Perkara di atas diperkukuhkan lagi oleh Nurkumala Awang (2012) yang menyatakan bahawa kajian saintifik oleh para pengkaji telah membuktikan bahawa perkara-perkara halal yang termaktub di dalam Quran dan Sunnah akan mendatangkan kebaikan dan manfaat kepada umat manusia. Manakala perkaraperkara haram yang telah diperjelaskan Islam secara saintifiknya membawa keburukan kepada umat 
manusia ini. Oleh yang demikian penggunaan konsep halal yang di bawa oleh Islam adalah perkara yang membawa kepentingan bukan sahaja umat Islam bahkan kepada umat manusia sejagat.

Selain daripada ciri-ciri dan definisi halal yang dinyatakan di atas, Nur Razuan Razali (2010) menyatakan bahawa aspek yang terkandung dalam konsep halal adalah merangkumi aspek Amalan Perkilangan Baik (GMP). GMP ini termasuklah kebersihan makanan, keselamatan makanan, pembungkusan, penghantaran, label, harga yang berpatutan dan hospitaliti dalam penghasilan sesuatu produk. Oleh itu, daripada kefahaman konsep halal mengikut definisi halal dari sumber undang-undang Islam seperti yang dibincangkan sebelum ini, suatu piawaian yang mempunyai panduan lengkap berdasarkan pengurusan Islam sangat diperlukan bagi memastikan penjenamaan halal benar-benar mengamalkan peraturan dan cara hidup Islam.

\subsection{METODOLOGI}

Kajian mengadaptasi kaedah kualitatif, iaitu satu proses yang dijalankan untuk memahami secara mendalam maksud bagi sesuatu kajian yang dijalankan (Sheild \& Twycross, 2003). Menurut Letts et al., (2007) dan Shenton (2003), metode kualitatif lebih berfokuskan kepada penerangan, penerokaan dan juga jauh dari penglibatan kiraan dan statistik. Oleh yang demikian, pengkaji telah memilih untuk menggunakan metode kajian perpustakaan bagi mendapatkan data yang berkaitan. Metode kajian perpustakaan ini merupakan satu cara sistematik terhadap maklumat-maklumat yang ingin diperoleh daripada sumber bacaan yang diperoleh (Suwanto, 2003). Kajian yang berfokuskan pencarian maklumat menerusi buku, jurnal, majalah, dan akhbar ini lebih bersifat subjektif. Metode kajian perpustakaan ini dikatakan bersifat subjektif kerana segala informasi yang diperoleh dari media bacaan ini adalah pencetus kepada komunikasi maklumat. Pengkaji akan memikirkan, menganalisis dan memproses segala maklumat yang diperoleh dan mengaitkan dengan makna yang tersurat dan tersirat di dalam teks. Suwanto (2003) juga menyatakan bahawa melalui metode perpustakaan ini pengkaji bakal melahirkan suatu pendekatan dan menemui jawapan bagi setiap objektif yang dinyatakan.

Terdapat dua jenis sumber yang boleh diperoleh dari metode perpustakaan ini, pertama sumber primer, dan yang kedua adalah sumber sekunder. Di dalam kajian ini pengkaji akan menjadikan sumber sekunder sebagai asas untuk menjawab semua kerangka objektif. Ini kerana sumber sekunder mampu untuk menyempurnakan sorotan penulisan, mengenal pasti standard halal dan mendalami teori yang diguna pakai. Selain itu, dokumen-dokumen yang berbentuk elektronik turut diguna pakai dalam memastikan maklumat yang diperoleh tidak hilang atau tertinggal.

Secara terperinci, langkah-langkah yang di ambil oleh pengkaji untuk menyelesaikan kerangka objektif kajian adalah seperti berikut; pertama, pengkaji memulakan kajian dengan mengumpulkan sebanyak mungkin maklumat dan informasi daripada buku, jurnal, sorotan akhbar dan lampiran majalah yang berkaitan dengan tajuk industri halal di Malaysia dan negara-negara luar yang teridiri daripada Indonesia, Singapura, Thailand dan Brunei; kedua, pengkaji akan menyusun segala maklumat yang diperoleh mengikut kategori masing-masing; seterusnya, pengkaji membuat perbandingan daripada maklumat yang diperoleh, langkah keempat kajian adalah menganalisis data kajian dengan menyenaraikan persamaan dan perbandingan dan yang terakhir sekali ialah menyimpulkan kajian.

\subsection{PENEMUAN DAN PERBINCANGAN}

\subsection{STANDARD PIAWAIAN HALAL DIGUNAKAN}

Di dalam Islam konsep halal amatlah perlu untuk memastikan barangan yang diguna pakai atau yang dimakan adalah suci, sihat, terhindar daripada perkara berbahaya, memabukkan dan menepati garis panduan 
yang di tetapkan oleh syara'. Barang-barang yang tidak halal (haram) adalah dilarang untuk diguna pakai oleh orang Islam. Makanan dan minuman yang tidak halal, sebaliknya dikelaskan sebagai syubhah harus dielakkan, sehingga mereka secara rasmi diisytiharkan halal (Nurkumala Awang 2012). Untuk membezakan antara halal dan haram sering menjadi suatu yang kompleks, ia merupakan suatu garis panduan yang menentukan keseragaman piawaian halal bagi memudahkan pengguna terutamanya pengguna Muslim. Walau bagaimanapun, piawaian halal ini mempunyai perbezaan di negara-negara di Asia Tenggara.

\subsection{STANDARD MALAYSIA}

Umumnya halal sering dikaitkan dengan makanan yang selamat, bersih dan berkhasiat, yang disediakan mengikut prinsip-prinsip Islam. Namun, konsep halal juga turut terpakai kepada produk penjagaan diri dan kosmetik, farmaseutikal, serta kewangan dan perkhidmatan lain (Standard Malaysia). Dalam memperkemaskan dan menambah keyakinan pengguna Islam terutamanya di Malaysia, aspek perundangan dan penguatkuasaan telah diperkemas dengan pengenalan undang-undang baru iaitu Akta Perihal Dagangan 2011 serta perundangan subsidiari di bawah akta tersebut yang berkaitan dengan persijilan dan logo halal. Malaysia menggunakan perkataan piawaian (standard) sebagai satu istilah untuk merujuk kepada usaha bagi menjadikan kehidupan lebih mudah menerusi peningkatan mutu barangan dan kecekapan perkhidmatan yang ditawarkan kepada pelanggan. Manakala dari segi penjelasan secara ilmiah, piawaian merupakan ciri-ciri keperluan yang diterbitkan bagi mewujudkan satu pemahaman umum di mana ia mengandungi ciri-ciri teknikal atau prinsip-prinsip yang tepat yang digunakan secara tetap sebagai suatu peraturan atau garis panduan.

Di Malaysia, usaha untuk membangunkan sesuatu piawaian industri terletak di bawah tanggungjawab SIRIM Berhad. SIRIM Berhad menerusi Jawatankuasa Piawaian Industri (Industry Standards Committee (ISC)) yang ditubuhkannya telah membangunkan pelbagai piawaian dan salah satu piawaian tersebut ialah MS1900:2005 Quality Management Systems: Requirement From Islamic Perspectives atau ringkasnya MS1900:2005. Standard MS1900:2005 ini merupakan salah satu piawaian halal yang telah dihasilkan oleh Jawatankuasa Teknikal Pengurusan Islam yang bernaung di bawah Jawatankuasa Standard Industri Bagi Standard Halal (ISCI), iaitu salah satu ISC yang diwujudkan oleh SIRIM Berhad. Berdasarkan kepada potensi ekonomi dan kelebihan yang menguntungkan ini, kerajaan Malaysia telah mula mengorak langkah untuk menjadikan Malaysia sebagai hab halal dunia (Mohd Noorizzuddin Nooh, 2009). Matlamat ini boleh di capai kerana banyak faktor, antaranya; permintaan produk halal yang tinggi di Malaysia (Mohd Nasir Nawawi et al, 2008), kemampuan untuk meningkatkan industri pembuatannya bagi menghasilkan produkproduk halal yang bermutu tinggi (Mohd Noorizzuddin Kutub Abd Rashid, 2009), dan juga kerana Malaysia adalah sebuah negara Islam yang dihormati sama ada di peringkat dunia seperti penglibatan dalam Organisasi Kerjasama Islam (Organisation of Islamic Cooperation (OIC)) dan negara-negara ASEAN (Rusdi Omar \& Mas Juliana Muthtaruddin, 2010).

\subsection{STANDARD HALAL INDONESIA}

Jumlah penduduk Indonesia pada tahun 2000 adalah 201241999 orang (BPS, 2000). Manakala jumlah penduduk Indonesia yang beragama Islam sebanyak 177528772 orang atau 88\%. Umat Islam secara khususnya perlu dilindungi dan mendapat keistimewaan dalam memperoleh produk halal melalui peraturan halal setiap produk sama ada makanan atau barangan keperluan termasuk ubat-ubatan dan alat kosmetik (Marina, 2003).

Oleh itu, keterangan serta label halal untuk suatu produk sangat penting bagi masyarakat Indonesia yang majoritinya adalah beragama Islam. Ia bertujuan supaya masyarakat memperoleh maklumat yang benar dan jelas tentang setiap produk yang dibeli dan diguna itu baik daripada segi kandungan dan kualitinya. Bagi masyarakat Indonesia apabila terdapatnya label halal, ia memberi jaminan tentang kehalalan sesuatu produk atau makanan (Keputusan bersama Menkes dan Menag, 1985). 
Pengeluar mahupun pengimport yang akan menghantar permohonan logo halal wajib diperiksa oleh petugas Tim Gabungan dari Majlis Ulama Indonesia dan Direktori Jendera Pengawasan Ubat dan Makanan yang ditunjuk oleh direktori Jenderal serta persetujuan berdasarkan Fatwa dari Majlis Ulama Indonesia. Hal ini telah menyebabkan kerajaan Indonesia mewujudkan Sistem Jaminan Halal yang mana sistem ini diperkenal dan dilaksanakan ke atas perusahaan yang memegang persijilan halal dalam rangka menjamin kesinambungan penghasilan produk halal (Apriyantono, 2001).

Sistem Jaminan Halal ini berdasarkan konsep Total Quality Management (TQM) yang terdiri daripada empat unsur utama, iaitu komitmen, keperluan pengguna, peningkatan tanpa penambahan pembiayaan, dan menghasilkan barang setiap waktu tanpa perlu kerja semula, tanpa penolakan dan tanpa pemeriksaan . Menurut Hakim (2002), Sistem Jaminan Halal ini dihuraikan secara bertulis dalam bentuk Manual Halal yang terdiri daripada:

1. Halal polisi

2. Panduan halal

3. Sistem pengurusan halal

4. Haram titik kawalan yang kritikal

5. Sistem audit halal dalaman

Seperti juga Malaysia, kerajaan Indonesia turut menubuhkan satu badan khas yang bertindak sebagai pemantau dan menjamin penggunaan logo halal terhadap sesuatu produk sama ada makanan, ubat-ubatan dan kosmetik iaitu Halal Assurance System (HAS). HAS 23000 juga dikenali sebagai (Halal Certification Standard) diletakkan dibawah pemerhatian Majelis Ulama Indonesia (MUI). HAS 23000 bertindak sebagai sistem pengurusan bersepadu dalam melaksana dan mengekalkan pengurusan bahan-bahan di dalam suatu produk, proses pengeluaran, produk, sumber manusia dan prosedur untuk mengekalkan kemampanan daripada proses pengeluaran halal mengikut keperluan MUI LPPOM (Lembaga Pengkajian Pangan, UbatUbatan dan Kosmetik Majlis Ulama Indonesia, 2014).

\subsection{STANDARD HALAL THAILAND}

Agama Buddha merupakan agama rasmi bagi negara Thailand. Walau bagaimanapun, populasi penduduk Thailand yang beragama Islam juga meningkat dari masa ke semasa sejajar dengan perkembangan umat Islam global hari ini. Kira-kira 35\% penduduk Thailand adalah beragama Islam (Development of Halal Industry in Thailand, 2009).

Bagi memastikan kelancaran dan kecekapan pengurusan halal, dan untuk menetapkan langkah dan kawalan kualiti produk halal dengan menggunakan logo halal, Jawatankuasa Islam Thailand telah mengeluarkan peraturan dikenali sebagai Regulation of the Central Islamic Committee of Thailand Concerning Halal Affair Operation of B.E 2552. Jawatankuasa Pusat Islam Thailand bertanggungjawab untuk menentukan dan mengumumkan penggunaan piawaian produk halal Thai yang selaras dengan prinsip Islam dan piawaian antarabangsa yang tidak bercanggah dengan prinsip Islam; meluluskan penggunaan logo halal ke atas produk halal; menjadi Badan Akreditasi Halal (HAB) serta menyelaras dan menyelia unit-unit yang berkaitan dengan operasi pengurusan halal (Sumalyasak, 2009).

Dengan terdapatnya badan-badan yang memantau dan mengawal kualiti produk halal di Thailand, ia dapat membantu pengguna terutamanya masyarakat Islam di Thailand mendapatkan produk yang dijamin serta terpelihara kehalalannya. Di samping itu juga, Thailand juga telah menubuhkan Sistem Halal Kualiti (HAL-Q) yang bertindak memantau industri makanan sama ada diperingkat perkilangan mahupun restoran. 


\subsection{STANDARD HALAL BRUNEI}

Standard halal di Brunei terletak di bawah Jabatan Hal Ehwal Syariah, Kementerian Hal Ehwal Agama Brunei Darussalam (Kementerian Hal Ehwal Agama Negara Brunei Darussalam, 2014). Bahagian Kawalan Makanan Halal (HFDC) telah bertanggungjawab untuk memantau penguatkuasaan persijilan halal terhadap produk serta makanan yang dikeluarkan oleh orang Islam di negara Brunei. Oleh yang demikian, negara Brunei mengguna pakai standard halal PBD 24:2007 yang mana merangkumi empat garis panduan iaitu:

1. Garis panduan untuk Persijilan Halal (BCG Halal 1)

2. Garis panduan untuk Audit Pematuhan Halal (BCG Halal 2)

3. Garis panduan Persijilan Halal bagi Juru audit (BCG Halal 3)

4. Garis panduan bagi audit Pengawasan Halal (BCG Halal 4)

Walau bagaimanapun, produk tempatan atau produk antarabangsa yang ingin memasuki pasaran global perlu melalui agensi lain yang bertindak sebagai separuh kerajaan yang dilantik oleh kerajaan negara Brunei.

\subsection{STANDARD HALAL SINGAPURA}

Di Singapura, Majlis Agama Islam Singapura (MUIS) merupakan badan yang bertanggungjawab mengenai aspek produk halal (Majlis Agama Islam Singapura, 2011). MUIS yang ditubuhkan pada 1968 di bawah Akta Pentadbiran Undang-undang Orang Islam 1968 adalah badan tunggal yang mengeluarkan sijil halal dan persijilan telah dimulakan sejak 1978. Seksyen 88A (1) memperuntukkan Majlis boleh mengeluarkan sijil halal berkaitan apa-apa produk, perkhidmatan atau aktiviti dan membuat peraturan untuk pemegang sijil halal bagi memastikan syarat-syarat di dalam undang-undang Islam dipenuhi semasa pengeluaran, proses, pemasaran atau pengiklanan produk, peruntukan perkhidmatan yang dijalankan dalam aktiviti tersebut. MUIS juga telah mengeluarkan satu garis panduan yang dinamakan sebagai Skim Persijilan Halal yang merangkumi produk, pembuatan makanan, penyimpanan, penyediaan, dan pengesahan produk halal. Hal ini kerana, meskipun Singapura bukanlah sebuah negara Islam namun, masih terdapat penduduk Islam minoriti yang tinggal di Singapura. Malahan, masyarakat Islam di negara-negara jiran seperti Malaysia dan Indonesia juga turut menjadikan Singapura sebagai destinasi pilihan sebagai bagi pelancongan sejajar dengan pengiktirafan Singapura sebagai salah sebuah negara maju

\subsection{PERBANDINGAN DAN PERSAMAAN STANDARD PIAWAIAN HALAL}

Di Malaysia peranan JAKIM bukan hanya mengeluarkan sijil halal semata-mata tetapi juga memantau dan melihat kesan ke atas generasi Islam akan datang dalam memastikan persijilan halal diberikan kepada pihak yang sepatutnya. Ini kerana terdapat kes dimana pengusaha yang ingin memohon sijil halal bagi produk yang menggunakan nama yang sinonim dengan perkara yang haram seperti 'champagne halal', 'bak kut teh halal', dan sebagainya. Hal ini dilihat, jika diberikan sijil halal kepada produk-produk tersebut di Malaysia maka apabila ke luar negara nanti generasi ini berkemungkinan beranggapan nama-nama tersebut adalah halal. Maka dengan itu, JAKIM telah memainkan peranannya untuk sentiasa memantau dengan teliti setiap sijil halal yang dikeluarkan.

Justeru itu, di dalam perkara 4.5 (g) Prosedur Persijilan Halal Malaysia menyatakan "permohonan persijilan halal ditolak sekiranya menggunakan perkataan atau nama yang sinonim dengan perkara yang haram seperti bak kut teh dan sebagainya". Dalam klausa 3.7.4 MS 1500:2009 juga menyebut "Makanan halal dan bahan perasa tiruan halal, hendaklah tidak menggunakan nama atau nama yang sinonim dengan istilah yang mengelirukan atau merujuk kepada makanan tidak halal seperti ham, bak kut teh, bir, rum dan sebagainya. 
Ini dijelaskan oleh Sheikh Dr Yusof Al-Qardhawi (2009) dalam prinsip ketujuh yang dinyatakan dalam buku halal Halal wal Haram fil Islam iaitu akan ada manusia akan membuat tipu daya dengan menggambarkan perkara yang haram itu dengan ditukar namanya kepada halal.

\section{Hadis Nabi SAW: “Nanti akan ada segolongan dari ummatku yang menganggap minuman khamar itu halal dengan menamakannya dengan nama-namanya yang lain” (HR Ahmad).}

Selain Malaysia, Majlis Ulama Indonesia juga menegaskan penggunaan jenama atau nama produk tidak boleh menggunakan nama yang cenderung kepada perkara yang haram atau amalan-amalan yang tidak sesuai dengan undang-undang Islam. Ini kerana MUI berpendapat tidak harus merosakkan fikiran generasi Islam yang telah rosak kini dengan perkara haram yang dihalalkan. Ia telah jelas di dalam al-Quran supaya manusia sentiasa memilih makan yang halal sahaja;

Firman Allah SWT dalam surah al-Baqarah : 168 : "Hai sekalian manusia, makanlah yang halal lagi baik dari apa yang terdapat di bumi, dan janganlah kamu mengikuti langkah-langkah syaitan; Kerana Sesungguhnya syaitan itu adalah musuh yang nyata bagimu."

MUI juga menyatakan penggunaan bentuk, ciri-ciri atau deria produk tidak perlu meniru produk haram contohnya seperti pembungkusan kordial minuman yang kebanyakan hari ini menyerupai pembungkusan minuman keras. Hal ini bukan sahaja akan mengelirukan pengguna Muslim, malah menyebabkan kerosakan kepada golongan muda Islam di masa hadapan.

Selain daripada ciri-ciri atau rupa bentuk pembungkusan, garis panduan penyembelihan juga berbeza di dalam standard halal yang diguna pakai. Standard halal yang diguna pakai di Malaysia contohnya di dalam MS 1500:2009 perkara 3.5.2 mengenai proses penyembelihan dan garis panduan tentang ciri-ciri penyembelih. Ini tercatat di dalam perkara 3.5.2 (a) 'penyembelih hendaklah dilakukan hanya oleh seorang Islam yang waras, baligh dan mengamalkan ajaran Islam, mempunyai pemahaman dan pengetahuan mengenai peraturan dan syarat asas berkaitan penyembelihan haiwan dalam Islam'. Berbeza dengan standard halal bagi penyembelihan yang diguna pakai di Thailand, Jawatankuasa Pusat Islam Thailand telah meletakkan peraturan penyembelihan di dalam THS 24000:2552 'National Halal standard for Thailand' disentuh mengenai penyembelih dari kalangan wanita dan kanak-kanak di dalam perkara 3.15.11 dan 3.15.12 yang mana menyatakan tidak ada perbezaan pendapat ulama Islam tentang haiwan untuk disembelih oleh seorang wanita Islam tetapi ianya adalah lebih baik dilakukan oleh lelaki Islam. Begitu juga dengan penyembelih tidak semestinya orang dewasa tetapi haruslah kanak-kanak yang sudah baligh dan mampu melaksanakan proses penyembelihan dengan baik.

\subsection{KESIMPULAN}

Kajian ini telah membuktikan bahawa standard halal yang digunakan di Malaysia dan beberapa negara di Asia Tenggara seperti, Indonesia, Thailand, Brunei dan Singapura adalah diselia oleh pihak bertanggungjawab. Sebagai contohnya, di Malaysia, JAKIM berperanan memantau dan mengeluarkan sijil halal. Ini dibantu SIRIM Berhad menerusi Jawatankuasa Piawaian Industri yang ditubuhkan dan telah membangunkan standard piawaian halal Malaysia. Manakala di Indonesia, Majlis Ulama Indonesia telah menubuhkan Lembaga Pengkajian Pangan, Ubat-ubatan dan Kosmetik sebagai badan yang bertanggungjawab dalam hal ehwal produk halal di Indonesia. Di Singapura pula, Majlis Agama Islam Singapura (MUIS) merupakan badan yang bertanggungjawab mengenai aspek produk halal.

Merujuk kepada standard halal yang digunakan, setiap negara mempunyai ciri-ciri jaminan yang tersendiri, Indonesia, menggunakan sistem Jaminan Halal yang berdasarkan kepada konsep total quality management yang terdiri daripada empat unsur utama, iaitu komitmen, keperluan pengguna, peningkatan tanpa penambahan pembiayaan, dan menghasilkan barang setiap waktu tanpa kerja semula, tanpa 
penolakan dan tanpa pemeriksaan. Brunei mengguna pakai standard halal PBD 24:2007 yang mana merangkumi empat garis panduan iaitu: Garis panduan untuk Persijilan Halal (BCG Halal 1), Garis panduan untuk Audit Pematuhan Halal (BCG Halal 2), Garis panduan Persijilan Halal bagi Juru audit (BCG Halal 3), Garis panduan bagi audit Pengawasan Halal (BCG Halal 4). Singapura menggunakan Skim Persijilan Halal yang merangkumi produk, pembuatan makanan, penyimpanan, penyediaan, dan pengesahan produk halal. Thailand, Jawatankuasa Pusat Islam bertindak untuk meluluskan penggunaan Logo Halal pada Produk Halal; mengakreditasikan Badan Persijilan Halal (HCB); menjadi Badan Akreditasi Halal (HAB); mengurus unit yang berkaitan dengan operasi hal ehwal standard halal. Manakala Malaysia, standard halal Halal merangkumi Pengeluaran, Penyediaan, Pengendalian dan Penyimpanan Garis Panduan Umum (MS 1500:2009).

\section{RUJUKAN}

Al-Quran, (2007). Al-Quran dan terjemahannya, Al-Quran Darul Iman Pustaka Darul Iman, KKDN: PQ/Q.1001/1.2/Q/155/2007

Habibah Abdul Talib dan Kahirul Anuar Mohd Ali, (2008). Aspek Kualiti Keselamatan dan Kesihatan Di Kalangan PKS Makanan: Satu Kajian. Jurnal Teknologi. 49 (E): 65-79.

Kementerian Hal Ehwal Agama Negara Brunei Darussalam (2014). Unit Undang-Undang, di ambil 27/3/2014 dari http://www.religiousaffairs-.

Kementerian Perdagangan Indonesia. (2012). Perniagaan Produk Halal Di Perancis, di ambil pada 4/8/2014 dari

http://www.itpclyon.fr/images/publication/130719.164222Market\%20Intellegent\%20Halal.p df

Letts, L., Wilkins, S., Law, M., Stewart, D., Bosch, J., \& Westmorland, M., (2007). Guidelines for Critical Review Form: Qualitative Studies (Version 2.0), di ambil pada 26/3/2014 dari http://www.srsmcmaster.ca/Portals/20/pdf/ebp/qualguidelines_version2.0.pdf

Majlis Agama Islam Singapura (2011). Halal Term and Certifiated, di ambil pada 4/8/2014 dari http://www.muis.gov.sg/cms/uploadedFiles/MuisGovSG/Halal/Muis\%20Halal\%-

20Terms\%20Conditions\%20for\%20EE\%20-\%20Updated\%20June\%202011.pdf

Mohd Noorizzuddin Nooh (2007). Penjenamaan Halal Satu Paradigma Baru. Malaysia: Universiti Sains Islam Malaysia.

Noorhaslinda Kutub Abd. Rashid, Noor Haslina Mohd Akhir, Mohd Nasir Nawawi, Rahim Ramli, \& Madziah Yasin (2008). Prospek Masa Depan produk Halal di Terengganu Serta Implikasi terhadap pembangunan Penduduk Setempat. Working Paper in Islamic Economics and Finance.

Nor Aini Haji Idris, Mohd Ali Mohd Noor (2013). "Analisis Keprihatinan Pengguna Muslim Terhadap Isu Halal-Haram Produk Melalui Pembentukan Indeks", Kertas kerja di bentangkan di Persidangan Kebangsaan Ekonomi Malaysia ke VIII (PERKEM VIII), Johor Bahru, 7 - 9 Jun 2013.

Norakilah Omar. (2007). Kefahaman Pengguna Terhadap Persijilan Halal pada Makanan Segera. Tesis Sarjana Muda. Universiti Malaysia Sabah.

Nur Razuan Razali (2010). Kajian ke Atas potensi Sabah Sebagai Hab Halal. Latihan Ilmiah. Universiti Malaysia Sabah. 
Nurkumala Awang (2012), Cabaran Pemakanan Halal, Mendidik Pengguna Bermaklumat. Portal Institut Kefahaman Islam Malaysia. http://www.ikim.gov.my/index.php/ms/utusan-malaysia/8504-cabaranpemakanan-halal-mendidik-pengguna-bermaklumat.

Lembaga Pengkajian Pangan, Ubat-Ubatan dan Kosmetik Majlis Ulama Indonesia, (2014). Policy CEROL SS 23000’s, di ambil dari http://e-lppommui.org/other/policy.php

Portal Rasmi Halal Malaysia (2011). Takrifan Halal, di ambil pada 25/3/2014 dari http://www.halal.gov.my/v3/index.php/ms/mengenai-pensijilan-halal/takrifan-halal

Rusdi Omar \& Mas Juliana Muthtaruddin, (2010). "Dasar Luar Malaysia Era Dato' Seri Mohd Najib Tun Razak: Keutamaan Dalam Aspek Hubungan Dua Hala”, Political Management and Policies in Malaysia. Di ambil pada 25/3/2013 dari http://repo.uum.edu.my/3173/1/S9.pdf

Shields, L. \& Twycross, A. (2003). The difference between Quantitative and Qualitative Research. Paediatric Nursing, 15(9).

Sumalyasak, S., (2009). Regulation of the Central Islamic Committee of Thailand Regarding Halal Affair $\begin{array}{llllll}\text { Operation of } & \text { B.E. 2552, di ambil }\end{array}$ http://www.halal.or.th/uploadfiles/regulation $\% 2052 \% 20(\mathrm{News}) . \mathrm{pdf}$

Suwanto, S. A. (2003). Kajian Pemakai Perpustakaan. Disampaikan pada Diklat Fungsional TOT Perpustakaan Propinsi Jateng.

Warta Eksport (2013). Peluang Perniagaan Produk Halal di Perancis, Indonesia: Gedung Utama Kementerian Perdagangan.

Yusuf Al-Qardawi (2013). The Lawful and The Prohibited in Islam. Malaysia: The Islamic Book Trust.

Zawanah Muhammad, Munir Md. Salleh \& Abdul Muhaimin Mahmood (2008). "Halal: Antara Tuntutan Agama dan Strategi Ekonomi”, Seminar Pentadbiran Hal Ehwal Islam Di Malaysia: Cabaran Semasa dan Perancangan Masa Depan. 6-7 Ogos 2008. Institut Kefahaman Malaysia, Kuala Lumpur. 